\title{
PENGARUH REBUSAN DAUN SIRIH MERAH (Piper Crocatum) TERHADAP PENURUNAN KADAR GULA DARAH PADA TIKUS PUTIH (Rattus norvegicus YANG DIINDUKSI Alloxan)
}

\author{
Kusuma Hati ${ }^{1}$, Meddy Setiawan ${ }^{2}$, Dian Yuliarta ${ }^{3}$ \\ Fakultas Kedokteran Universitas Muhammadiyah Malang,Jl. Bendungan Sutami 188 A Sumbersari, \\ Lowokwaru, Kota Malang, 65145, Indonesia, (0341) 582060
}

\begin{abstract}
ABSTRAK
Latar Belakang : Pengobatan diabetes mellitus dengan obat anti diabetes sintetis sering menimbulkan efek samping. Untuk itu perlu dikembangkan system pengobatan tradisional sebagai alternatif pengobatan diabetes yang aman dan mudah cara pembuatannya, yaitu daun sirih merah (Piper crocatum). Tujuan penelitian : Untuk membuktikan adanya pengaruh rebusan daun sirih merah terhadap penurunan kadar gula darah pada tikus putih yang diinduksi alloxan Metode Penelitian : Jenis penelitian eksperimental, populasi tikus putih jantan dengan sampel 24 ekor yang terdiri dari 6 kelompok perlakuan dan 4 kali pengulangan. Alloxan diberikan pada hari ke-8 sampai dengan hari ke-14 dan rebusan daun sirih merah diberikan pada hari ke-15 sampai hari ke-28. Pemeriksaan kadar gula darah pada tikus putih dilakukan pada hari ke-7, ke14, dan ke-28. Hasil Penelitian : Hasil uji One Way Anova menunjukan adanya pengaruh perlakuan terhadap penurunan kadar gula darah tikus putih secara sangat bermakna $(\mathrm{p}<0,01)$. Koefisien korelasi $=0,925$ menunjukan korelasi positif yang kuat antara dosis rebusan daun sirih merah dengan penurunan kadar gula darah. Kesimpulan : Pemberian rebusan daun sirih merah dapat menurunkan kadar gula darah tikus putih yang diinduksi alloxan.
\end{abstract}

Kata kunci : Daun sirih merah, kadar gula darah

\section{ABSTRACT}

Backgound: synthetic antidiabetic therapy potentially showed some side effects. To avoid these side effects, needs to improve the traditional therapy system as an alternative of safe and easy to make of diabetes therapy, that is Piper crocatum leaves Objective : Prove the existence of the influence boiled Piper crocatum leaves solution to reducing of blood glucose level on the white rats (Rattus norvegicus) that induced by alloxan Method: Type of experimental research, the population of white rat with the male sample consisted of 24 rats from 6 treatment groups and replayed 4 times. Alloxan was given on 8th through 14th day and the solution of boiled of sirih merah leaves was given on 15th day until 28th day. Blood glucose measurement could be made on 7th day, 14th day and 28th day. Result : one way Anova test showed that the treatment had very significant differences at 0,01 level. Correlation coefficient $=0,925$ showed that there was a close positive correlation between boiled Piper crocatum leaves dose with reduced blood glucose level. Conclusion : the treatment of boiled Piper crocatum leaves could reduce the white rats blood glucose level which induced by alloxan

Key word : Piper crocatum leaves, blood glucose level

\section{PENDAHULUAN}

Masa transisi demografi akibat keberhasilan upaya menurunkan angka kematian, dapat menimbulkan transisi epidemiologis, dimana pola penyakit bergeser dari infeksi akut ke penyakit degeneratif yang menahun. Salah satu diantaranya yang berkaitan erat dengan penyakit metabolisme dan cenderung akan mengalami peningkatan sebagai dampak adanya pergeseran perilaku pola konsumsi gizi makanan adalah diabetes mellitus (Suharmiati, 2004).

Diabetes mellitus merupakan penyakit yang ditandai dengan kadar glukosa darah yang melebihi normal sebagai akibat dari tubuh yang kekurangan insulin relatif maupun absolut, dimana ditandai dengan gejala poliuria, polidipsia, polifagia, penurunan berat badan, lemas dan kematian (Rahardja, 2002). Penyebab diabetes mellitus adalah aktivitas insulin yang tak memadai baik karena sekresi insulinnya berkurang (IDDM) atau karena adanya resistensi insulin di tempat reseptor jaringan yang peka insulin (NIDDM) (Suharmiati, 2003).

Selama penanggulangan diabetes, obat hanya merupakan pelengkap dari diet. Obat diabetes oral mungkin berguna untuk penderita yang alergi terhadap insulin atau yang tidak menggunakan suntikan insulin. Sementara penggunaannya harus dipahami, agar ada kesesuaian dosis dengan indikasinya, tanpa menimbulkan hipoglikemia. Karena obat anti diabetes oral kebanyakan memberikan efek samping yang tidak diinginkan, maka para ahli mengembangkan sistem pengobatan tradisional untuk diabetes mellitus yang relatif aman dan mudah dalam pembuatannya (Studiawan dan Santosa, 2005). 
Selain itu, untuk mencari pengobatan saat ini sangat memerlukan biaya dan sebagai alternatif banyak anggota masyarakat untuk kembali ke pengobatan tradisional yang dapat dipercaya (Zulkifli, 2004).

Dari beberapa sumber informasi, banyak tanaman obat yang digunakan sebagai penurun kadar glukosa darah, salah satunya adalah daun sirih merah (Nugroho, 2002). Sebelumnya daun sirih merah hanya digunakan untuk tanaman hias dan kelengkapan upacara adat saja (Manoi, 2007). Pada tahun 2002 seorang ahli tanaman herbal menemukan daun sirih merah dan digunakan untuk mengobati diabetes mellitus dalam bentuk rebusan, ternyata dalam satu minggu kadar gula darah menurun secara signifikan (Sadewo, 2005) Dalam daun sirih merah terkandung senyawa fitokimia yakni alkaloid, saponin, tanin dan flavonoid. Secara empiris sirih merah dapat menyembuhkan berbagai jenis penyakit seperti diabetes mellitus, hepatitis, batu ginjal, menurunkan kolesterol, mencegah stroke, asam urat, hipertensi, radang liver, radang prostat, radang mata, keputihan, maag, kelelahan, nyeri sendi dan memperhalus kulit. Daun sirih merah lebih banyak mengandung senyawa-senyawa kimia yang penting untuk berbagai macam penyakit daripada jenis daun sirih lainnya seperti daun sirih hijau dan daun sirih hitam (Sadewo, 2005).

Potensi sirih merah sebagai tanaman obat multi fungsi sangat besar sehingga perlu ditingkatkan dalam penggunaannya sebagai bahan obat modern (Manoi, 2007).

Dalam penelitian sebelumnya yang dilakukan pada tahun 2005, aktivitas anti hiperglikemik ekstrak air daun sirih merah ditunjukkan setelah 2 hari pemberian daun sirih merah dan dosis yang lebih baik digunakan adalah 1000x dosis daonil dengan dosis $20 \mathrm{~g} / \mathrm{Kg} \mathrm{BB}$.

\section{BAHAN DAN METODE}

Penelitian ini merupakan true experimental dengan desain penelitian Pre-Post test control dengan dilakukan pengukuran kadar glukosa darah sebelum dan sesudah perlakuan, dengan populasi berupa tikus jantan galur wistar (Rattus novergicus strain wistar) yang kondisinya sehat dan ditandai dengan gerakannya yang aktif.

Sampel dalam penelitian ini berjumlah 24 ekor tikus putih jantan strain wistar dengan berat 150 - 200 gram, berusia $2-3$ bulan, sehat (ditandai dengan gerakannya yang aktif), suhu rectal ratarata $37,5^{\circ} \mathrm{C}$, bulu tebal dan berwarna putih.

Penelitian ini menggunakan 6 kelompok perlakuan yaitu, satu kelompok kontrol positif (tikus yang diinduksi alloxan tanpa pemberian daun sirih merah) dan lima kelompok perlakuan (tikus yang diinduksi alloxan dan dengan pemberian daun sirih merah pada dosis $0,25 \mathrm{ml}, 0,5$ $\mathrm{ml}, 0,75 \mathrm{ml}, 1,5 \mathrm{ml}$, dan $3 \mathrm{ml}$. tiap kelompok perlakuan diulang sebanyak empat kali,

Pada penelitian ini terdiri dari lima tahap, yaitu: Proses Adaptasi, pembuatan rebusan daun sirih merah, pembuatan larutan alloxan, perlakuan pada tikus, pemeriksaan kadar gula darah. Selanjutnya dilakukan analisis data.
Proses adaptasi sampel dilakukan di dalam kandang yang diletakkan di laboratorium selama 7 hari, tikus diberi makanan BR 1 sebanyak dua kali sehari, Sedangkan untuk minum tikus diberi aquades.

Pembuatan rebusan daun sirih merah sebanyak 200 gram diambil yang cukup tua dan tidak terlalu muda dicuci bersih, kemudian direbus bersama 1 liter air hingga volumenya menjadi $100 \mathrm{ml}$.

Besarnya dosis rebusan daun sirih pada subyek penelitian dihitung berdasarkan jumlah rata-rata daun sirih merah yang dikonsumsi oleh manusia kemudian dikonversikan ke subyek, konsumsi rata-rata daun sirih merah segar pada manusia adalah setengah gelas $(100 \mathrm{ml})$ dan frekuensi penggunaanya adalah 3 kali sehari menurut Sudewo (2005). Bila rata-rata berat badan orang Indonesia adalah $60 \mathrm{~kg}$ maka diperoleh dosis rebusan daun sirih merah sebesar $300 \mathrm{ml}$ dengan mengambil rata-rata berat badan tikus sebesar $150 \mathrm{gr}$ /ekor maka diperoleh dosis daun sirih merah pada tikus sebesar $0,75 \mathrm{ml} /$ ekor. Berdasarkan perhitungan diatas, peneliti menggunakan empat dosis yang berbeda yaitu $0,25 \mathrm{ml}, 0,5 \mathrm{ml}, 0,75 \mathrm{ml}, 1,5 \mathrm{ml}$, dan $3 \mathrm{ml}$ daun sirih merah.

Pembuatan Larutan Alloxan dengan mencampur serbuk alloxan tetrahidrat 1,6\% dengan larutan $\mathrm{NaCl} 0,9 \%$ kemudian diencerkan hingga diperoleh $100 \mathrm{ml}$. Penentuan dosis alloxan dengan menghitung kebutuhan alloxan per hari sesuai berat badan tikus. Pada penelitian ini rata-rata berat badan tikus jantan adalah $150 \mathrm{gr}$, sedangkan dosis toksik alloxan (konsentrasi $1,6 \%$ b/v) pada hewan coba sebesar $1 \mathrm{ml} / \mathrm{kg}$ BB. Dengan demikian dosis alloxan yang dibutuhkan bagi tiap ekor tikus putih jantan adalah $0,15 \mathrm{ml} /$ ekor.

Pada penelitian yang dilakukan pada tahun 2004 menjelaskan uji terhadap tikus hiperglikemia yakni mencit jantan dewasa galur ddY diinduksi dengan alloxan volume $0,2 \mathrm{ml} / 200 \mathrm{gr}$ BB secara intravena pada ekor mencit. Setelah penyuntikan hewan dikembalikan ke kandang dan diberi makan seperti biasa.

Tikus tikus yang sudah mengalami adaptasi (teraklimatisasi) dikelompokkan menjadi 6 kelompok untuk mendapatkan perlakuan yang berbeda pada tiap-tiap kelompok, antara lain: Kelompok kontrol positif, kelompok tikus yang diinduksi dengan alloxan 1,6 b/v 0,15 ml/ekor dan rebusan daun sirih merah dengan dosis $0,25 \mathrm{ml} /$ ekor, 0,5 ml/ekor, 0,75 ml/ekor, 0,15 ml/ekor, dan $3 \mathrm{ml} /$ ekor.

Alloxan tetrabidrat diberikan secara subkutan pada tikus putih jantan, satu kali sehari selama 7 hari berturut-turut sejak hari ke-8, sedangkan rebusan daun sirih merah diberikan secara per oral dengan sonde setiap hari, satu kali sehari selama 2 minggu mulai hari ke-15 sampai hari ke-28.

Pemeriksaan kadar glukosa darah dengan mengukur gula darah acak pada saat sebelum perlakuan dan setelah aloksanisasi dan dengan metode enzimatik GOD-PAP pada saat akhir penelitian. Menurut Kusumawati (2004), kadar glukosa darah tikus dalam kondisi normal adalah 50-135 $\mathrm{mg} / \mathrm{dl}$.

Pemeriksaan kadar glukosa darah pada tikus dilakukan pada hari ke-7, ke-14, dan ke-28. Pemeriksaan pada hari ke7 untuk mengetahui kadar gula darah sebelum perlakuan, pada hari ke-14 untuk mengetahui efek hiperglikemik dari 
alloxan. Pada hari ke-28 untuk mengetahui efek pemberian rebusan daun sirih merah yang merupakan akhir dari perlakuan terhadap hewan coba.

Pengukuran kadar glukosa darah dalam penelitian ini menggunakan metode enzimatik GOD-PAP dengan prosedur sebagai berikut: Mengambil sampel darah sebanya $1 \mathrm{ml}$ (20 tetes), dilakukan pada

pembuluh darah tikus dengan syringe $3 \mathrm{ml}$ dan jarum suntik. Sampel darah dimasukkan ke dalam kuvet yang sudah diberi label masingmasing dan didiamkan selama 15 menit. Sampel darah disentrifugekan dengan kecepatan 8.000 rpm selama 10 menit. Mengambil supernatant (serum) sebanyak $20 \mu$ l dengan mikropipet kemudian dimasukan ke dalam kuvet yang masing-masing bertanda B (Blanko), S (Sampel) dan St (Standart). Masing-masing sampel didalam kuvet tersebut dicampur dengan larutan pereaksi GOD sebanyak $20 \mu$ l. Setelah tercampur rata, sampel dipanaskan selama 20 menit dengan suhu $30^{\circ} \mathrm{C}$ (suhu kamar), kemudian membaca absorbansinya pada spektrofometer dengan panjang gelombang $500 \mathrm{~nm}$ dan nilai absorbansi standart 0,990, sedangkan blanko (aquades) sebagai titik nol.

Untuk analisa data, parameter yang digunakan adalah penurunan kadar glukosa darah setelah pemberian rebusan daun sirih merah selama 2 minggu ( hari ke-14 dan ke-21) dari kelompok II sampai dengan kelompok VI, yang sebelumnya diinduksi dengan alloxan selama 1 minggu. Penurunan kadar glukosa darah dianalisis dengan uji One way ANOVA pada tingkat kepercayaan 95\% (Sudjana, 1982) Kemudian dilanjutkan dengan uji regresi untuk mengetahui ada tidaknya hubungan dosis rebusan daun sirih merah dengan respon (kadar glukosa darah) dan mengetahui seberapa kuat hubungan tersebut kadar gula darah tikus sebelum dilakukan perlakuan apapun menunjukkan kisaran normal yaitu antara 50-135 mg/dl. Setelah proses aloksanisasi, tikus pada semua kelompok mengalami hiperglikemia. Kemudian rebusan daun sirih merah diberikan selama 2 minggu pada kelompok II sampai dengan VI pada dosis $0,25 \mathrm{ml}, 0,5 \mathrm{ml}, 0,75 \mathrm{ml}, 1,5 \mathrm{ml}$, dan $3 \mathrm{ml}$.

\section{HASIL DAN PEMBAHASAN}

Tabel 1. Rerata kadar gula darah tikus putih

\begin{tabular}{|c|c|c|c|c|}
\hline \multicolumn{5}{|c|}{ Rerata Kadar gula darah tikus putih(mg/dl) } \\
\hline Kelompok & $\begin{array}{l}\text { Sebelum } \\
\text { perlakuan }\end{array}$ & $\begin{array}{l}\text { Setelah } \\
\text { aloksan }\end{array}$ & $\begin{array}{l}\text { Akhir } \\
\text { perlakuan }\end{array}$ & á(aloksanisasi-akhir) \\
\hline kontrol + & 109,01 & 228,26 & 226,50 & 1.76 \\
\hline $0,25 \mathrm{ml}$ & 106,27 & 229,50 & 174,38 & 55.12 \\
\hline $0,5 \mathrm{ml}$ & 109,18 & 230,12 & 153,88 & 76.23 \\
\hline $0,75 \mathrm{ml}$ & 108,21 & 227,82 & 134,09 & 93.72 \\
\hline $1,5 \mathrm{ml}$ & 106,00 & 228,62 & 118,28 & 110.33 \\
\hline $3 \mathrm{ml}$ & 109,27 & 222,52 & 112,63 & 109.89 \\
\hline
\end{tabular}

Hasil akhir penelitian menunjukkan rata-rata kadar gula darah tertinggi ada pada kelompok I (226,502 mg/dl) yang tidak diberikan rebusan daun sirih merah atau sebagai kelompok kontrol positif, sedangkan kadar gula darah terendah pada kelompok VI dengan rata-rata 112,633 mg/ dl. Pada rerata penurunan juga menunjukan perbedaan yang sangat jauh dimana pada kelompok I rerata penurunanya terkecil yaitu $1,767 \mathrm{mg} / \mathrm{dl}$ dan rerata penurunan tertinggi pada kelompok $\mathrm{V}$ dengan rerata $110,336 \mathrm{mg} / \mathrm{dl}$.
Dari hasil akhir penelitian didapatkan bahwa kelompok kontrol positif memiliki kadar gula paling tinggi yaitu 226,502 $\mathrm{mg} / \mathrm{dl}$, hal ini dikarenakan efek alloxan yang menyebabkan tikus putih dalam keadaan hiperglikemik serta tidak adanya perlakuan pemberian daun sirih merah. Pada kelompok I terjadi penurunan walaupun sedikit dikarenakan terjadi regenerasi sel beta pankreas. Hal ini sesuai dengan penelitian Chaungale, Panaskar, Gurao, dan Arvindeka (2007) yang mengatakan bahwa regenerasi dan neogenesis pada hari ke 12. Pada kelompok II dan III, tikus putih masih dalam keadaan hiperglikemik tetapi kadar gula darahnya lebih rendah dari kelompok kontrol positif, karena pada kedua kelompok tikus ini sudah diberikan rebusan daun sirih merah yang dosisnya ternyata belum cukup menurunkan kadar gula darah mendekati normal. Pada kelompok IV, V, VI kadar gula darah tikus sudah berada pada kisaran normal, dan pada kelompok perlakuan VI menunjukan kadar gula darah terendah yaitu $112,663 \mathrm{mg} / \mathrm{dl}$ dengan penurunan sebesar $109,804 \mathrm{mg} / \mathrm{dl}$

Selanjutnya dilakukan analisis data. uji one way ANOVA menunjukkan bahwa nilai sig $=0,000$ yang lebih kecil dari pada $\mathrm{p}(0,01)$ yang berarti terdapat pengaruh yang bermakna antara perlakuan pemberian rebusan daun sirih merah terhadap penurunan kadar gula darah pada tikus putih.

Tabel 2. hasil uji turkey $1 \%$

\begin{tabular}{llc}
\hline Perlakuan & Rerata & Notasi \\
\hline K+ & 1.766784 & $\mathrm{a}$ \\
Kel 2 & 55.12367 & $\mathrm{~b}$ \\
Kel 3 & 76.23675 & $\mathrm{c}$ \\
Kel 4 & 93.72792 & $\mathrm{~d}$ \\
Kel 5 & 109.894 & $\mathrm{~d}$ \\
Kel 6 & 110.3357 & $\mathrm{~d}$ \\
\hline
\end{tabular}

Dari tabel diatas menunjukan bahwa angka yang diikuti huruf yang sama berarti tidak berbeda secara signifikan pada uji Tukey 1\%. Artinya pada kelompok kontrol dengan kelompok I dan kelompok II memiliki perbedaan rerata penurunan yang signifikan. Pada kelompok IV, V dan VI ternyata menunjukan penurunan kadar gula darah yang tidak berbeda secara siginifikan. Dan kelompok control berbeda secara signifikan penurunan kadar gula darahnya dengan kelompok IV,V, dan VI.

Hasil uji korelasi antara perlakuan dan penurunan gula darah menunjukkan bahwa nilai sig $=0,000$ yang berarti kurang dari $\mathrm{p}(0,01)$ sehingga dapat disimpulkan terdapat korelasi yang sangat bermakna antara banyaknya dosis pemberian rebusan daun sirih merah dengan penurunan kadar gula darah. Korelasi yang terjadi pada penelitian ini merupakan korelasi yang berbanding lurus, artinya kenaikan dosis rebusan daun sirih merah menyebabkan kenaikan penurunan gula darah tikus putih. Hal ini ditunjukkan dengan nilai pearson correlation $=0,925$. 


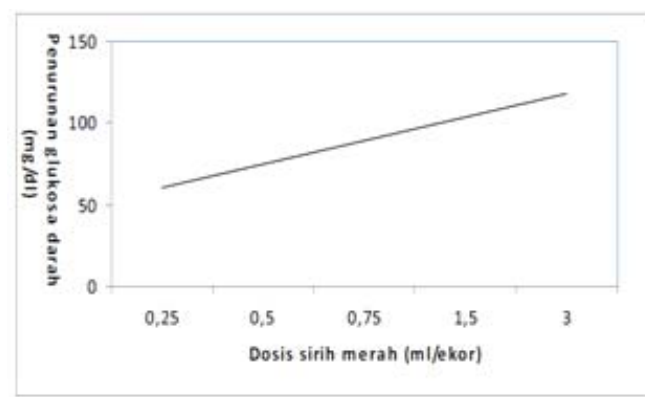

Grafik 1. Gambar hasil uji regresi

Hasil Uji regresi menunjukkan bahwa persamaan yang digunakan untuk menentukan hubungan antara dosis rebusan daun sirih merah terhadap penurunan gula darah akhir tikus putih adalah: $\mathrm{Y}=2,138+20,679(\mathrm{X})$ dengan nilai koefisien determinasi $\mathrm{R} 2=0,856$. Persamaan tersebut cocok, hal ini dikarenakan nilai sig anova regresi $=0,000<$ $\mathrm{p}(0,01)$. koefisien determinasi $\mathrm{R} 2=0,856$. Berarti, pengaruh penurunan kadar gula darah tikus putih dipengaruhi oleh dosis rebusan daun sirih merah sebesar 85,6 \%

Penurunan kadar gula darah tikus putih setelah diberi rebusan daun sirih merah dapat dijelaskan melalui dua mekanisme utama yaitu secara intra pankreatik dan ekstra pankreatik. (Mc Whorter, 2001).

Mekanisme intra pankreatik bekerja dengan cara memperbaiki sel $\beta$ pankreas yang rusak dan melindungi sel $\beta$ dari kerusakan serta merangsang pelepasan insulin. Kemampuan

ini dimiliki oleh alkaloid dan flavonoid (Li MX, 2001: Ogata, 2005). Alkaloid terbukti mempunyai kemampuan regenerasi sel $\beta$ pankreas yang rusak (Li MX, 2001: Ogata, 2005). Peningkatan sekresi insulin diakibatkan oleh adanya efek perangsangan saraf simpatis dari alkaloid yang berefek pada peningkatan sekresi insulin. Flavonoid mempunyai efek sebagai antioksidan sehingga dapat melindungi kerusakan sel pankreas dari radikal bebas. (Agrawal, 2000).

Mekanisme ekstra pankreatik dapat berlangsung melalui berbagai mekanisme. Alkaloid menurunkan glukosa darah dengan cara menghambat absorbsi glukosa di usus, meningkatkan transportasi glukosa di dalam darah, merangsang sintesis glikogen dan menghambat sintesis glukosa dengan menghambat enzim glukosa 6-fosfatase, fruktosa 1,8-bifosfatase serta meningkatkan oksidasi glukosa melalui glukosa 6-fosfat dehidrogenase. Glukosa 6-fosfatase dan fruktosa 1,6-bifosfatase merupakan enzim yang berperan dalam glukoneogenesis. Penghambatan pada kedua enzim ini akan menurunkan pembentukan glukosa dari substrat lain selain karbohidrat. Saponin bekerja dengan cara menurunkan absorbsi glukosa di usus, menghambat transporter glukosa GLUT 1, meningkatkan pemanfaatan glukosa di jaringan perifer dan penyimpangan glikogen serta peningkatan sensitifitas reseptor insulin di jaringan (McWhorter, 2001; Agrawal, 2000).

Dalam percobaan sebelumnya yang dilakukan Mega Safitri, daun sirih merah terbukti dapat menurunkan kadar gula darah tikus putih sampai dengan kondisi normal, dimana tikus putih diinduksi dengan alloxan dan diberi ekstrak daun sirih merah dengan dosis $5 \mathrm{~g} / \mathrm{kgBB}, 10 \mathrm{~g} /$
$\mathrm{kgBB}, 20 \mathrm{~g} / \mathrm{kgBB}$ selama 10 hari. Hasilnya, dosis ekstrak daun sirih merah dengan dosis $20 \mathrm{~g} / \mathrm{kgBB}$ merupakan dosis paling efektif untuk menurunkan kadar gula darah tikus putih. Perbedaan dalam penelitian ini adalah, penelitian ini menggunakan rebusan daun sirih merah, dimana diharapkan masyarakat lebih mudah membuatnya sebagai obat tradisional untuk diabetes mellitus daripada mengolahnya dalam bentuk ekstrak yang lebih rumit cara pembuatanya (Studiawan dan Santosa, 2005).

\section{SIMPULAN}

Terdapat pengaruh yang bermakna antara perlakuan pemberian rebusan daun sirih merah terhadap penurunan kadar gula darah pada tikus putih yang diinduksi alloxan dan terdapat korelasi yang sangat bermakna antara perlakuan dan penurunan glukosa darah, dimana korelasinya berbanding lurus. Dosis rebusan daun sirih merah yang paling efektif dalam menurunkan kadar gula darah tikus putih adalah $3 \mathrm{ml} / 150$ gram BB/hari.

\section{DAFTAR PUSTAKA}

Adam, JMF. 2000. Klasifikasi dan Kriteria Diagnosis Diabetes Mellitus yang Baru. Ujung Pandang. Fakultas Kedokteran Universitas Hasanuddin.

Agrawal DP.2000. Diabetes and Traditional Medicine: New Reseach. (http:/ www.infinity foundation. com/ mandala/t_es/t_es_agraw_diabetes.htm. diakses November 2009

Azrul Azwar, 1994, Peran Pengobat Tradisional Sebagai Mitra Pelayanan Kesehatan modern, Majalah Kesehatan Masyarakat Indonesia, Jakarta. No.01/ Th.XXI. hlm.1.

Darmansjah. 2004. Dasar Toksikologi: Farmakologi dan Terapi Edisi 4. Jakarta: FKUI. Hal: 762 - 780.

Foster . D.W.2000. Diabetes mellitus. Prinsip-Prinsip Ilmu penyakit Dalam. Horrison.Jakarta:EGC:2196-2217.

Gustaviani, Reno. 2006. Buku Ajar Ilmu Penyakit Dalam Jilid III Edisi IV.Jakarta: Balai Pustaka FKUI

Hariana, Drs. H. Arief.2008. Tumbuhan Obat dan Khasiatnya, seri 3 .Jakarta: Penebar Swadaya

Kusumawati, D. 2004. Bersahabat dengan Hewan coba. UGM Press. Yogyakarta.

Li MX, Akira Kazuhito Y. , Takao K., Qing HS., Hajime K., Jong CC. Pancreatic islet Regewneration by ephedrine in mice with streptocin induced Diabetes.(http:// www.findarticles. com/p/articles/mi_mOHKP/ is_2001_SummerFall/ai_81596700. diakses November 2009)

Manoi, Feri .2007. Sirih Merah Sebagai Tanaman Obat Multi Fungsi. (http:/ / balittro. litbang.deptan.go.id . Diakses tanggal 11 October, 2009, 18:36 )

McWhorter LS. Biologycal Complementary Therapies: A focus on Botanical Products in Diabetes.2001. (http:// spectrum.diabetesjournals.org/cgi/content/full/14/4/ 199, diakses November 2009).

Mulder H, Samuel GM, Christer B, Frank S, Bo A.2002. Islet Amyloid Polypeptide (Amylin)-Deficiebt Nice Develop a More Severe Fonn of Aloxan - induced Diabetes. (http:// ajpendophysiology.org/cgi/content/ full/278/4/E684, diakses November 2009). 
Murray, R. K. Granner, D. K. mayes, P.A: Radwel., V.W.2003. Harper Biochemistry.25/E, diterjemahkan : Hartono A (ed)dalam Biokimia Harper EGC.Jakarta,581-597

Nugroho.2002.: Sudarsono, Pudjoarinto, A. , Gunawan D., Wahyuono S., Donatus I.A., Drajad M.,Wibowo S.,dan Ngatidjan, 1996, Tumbuhan Obat, 20-25. Yogyakarta. Pusat Penelitian Obat Tradisional Universitas Gajah Mada

Nwanko, EA, Samdi, LM,.2008. Alloxan-Induced Diabetes in Rats : Journal of Pharmacology and Toxicology. Universitas of Maiduguri, Nigeria.

Ogata T, Lei L, Satoko Y, Yuji T, Izumi T, Kazauo U. Itaru k.2005. Promotion of B-Cell Differentation by Conophylline in Fetal and Neonatal Rat Pancreas. (http:// diabetes.diabetesjournals.org/egi/contem/full/53/10/ 2596 , diakses November 2009).

Powers, AC. Diabetes Mellitus. Ln : Harrison's Principle of Internal Medicine. USA: Mc Graw Hill Companies, Inc,2005; 2152-2168. Rho, hye-won. Ji-Nalee, Ki rho hyung, Park Byung-Hyun and park Jinwooo. 2000. Proactive Mechanism of Glucose Against Alloxan Induced Bcell Damage: Pivotal Role of ATP. Korea Eksperimental and Molecular Medicine Vol 23 No 1: 12-17.

Ruiz \& Pav. Sacks D. B. 2001. Carbobydrates in Tietz. Fundamentalis of Clinical Chemistry Eds Burtis C. A. A Swood E. R., 5th Edition, W.B. Saunders Company, USA.

Schteingart, DE.2005. Konsep Klinis Proses-Proses penyakit: Metabolisme Glukosa dan Diabetes Mellitus, Jakarta: Absolut; 2004. p. 63-65.

Setiawan, Meddy.2008. Buku Ajar Endokrin.Malang: Fakultas Kedokteran Universitas Muhammadiyah Malang

Studiawan, H dan Santosa MH. 2005. Uji Aktivitas Penurun Kadar Glukosa Darah Ekstrak Daun Eugenia polyantha pada Tikus yang Diinduksi Aloksan. Surabaya. Bagian Ilmu Bahan Alam, Fakultas Farmasi, Universitas Airlangga

Sudewo, B.. 2005. Basmi Penyakit dengan Sirih Merah, PT. AgroMedia Pustaka, Yogyakarta.

Sudjana.1982.Metode Statistika. Penerbit Tarsito. Bandung. Suharmiati. 2000. Pengujian Bioaktivitas Anti Diabetes Mellitus Tumbuhan Obat. Jurnal Penelitian Bahan Penelitian dan Pengembangan Kesehatan Pusat Penelitian dan Pengembangan Pelayanan dan Teknologi KesehatanDepartemen Kesehatan RI, Surabaya, Cermin Dunia Kedokteran No.140, 2003. 
